\title{
Highly stable meso-diaminopimelate dehydrogenase from an Ureibacillus thermosphaericus strain A1 isolated from a Japanese compost: purification, characterization and sequencing
}

Hironaga Akita', Yasuhiro Fujino ${ }^{2}$, Katsumi Doi ${ }^{3}$ and Toshihisa Ohshima ${ }^{3^{*}}$

\begin{abstract}
We screened various thermophiles for meso-diaminopimelate dehydrogenase (meso-DAPDH, EC 1.4.1.16), which catalyzes the NAD(P)-dependent oxidative deamination of meso-diaminopimelate, and found the enzyme in a thermophilic bacterium isolated from compost in Japan. The bacterium grew well aerobically at around $55^{\circ} \mathrm{C}$ and was identified as Ureibacillus thermosphaericus strain A1. We purified the enzyme about 47-fold to homogeneity from crude cell extract using five successive purification steps. The molecular mass of the purified protein was about $80 \mathrm{kDa}$, and the molecule consists of a homodimer with the subunit molecular mass of about $40 \mathrm{kDa}$. The optimum $\mathrm{pH}$ and temperature for the catalytic activity of the enzyme are about 10.5 and $65^{\circ} \mathrm{C}$, respectively. The enzyme is highly selective for meso-diaminopimelate as the electron donor, and NADP but not NAD can serve as the electron acceptor. The $K_{\mathrm{m}}$ values for meso-diaminopimelate and NADP at $50^{\circ} \mathrm{C}$ and $\mathrm{pH} 10.5$ are $1.6 \mathrm{mM}$ and $0.13 \mathrm{mM}$, respectively. The nucleotide sequence of this meso-DAPDH gene encodes a 326-amino acid peptide. When the gene was cloned and overexpressed in Escherichia coli Rosetta (DE3), the specific activity in the crude extract of the recombinant cells was about 18.0-fold higher than in the extract from U. thermosphaericus strain A1. This made more rapid and simpler purification of the enzyme possible.
\end{abstract}

Keywords: meso-Diaminopimelate dehydrogenase, Ureibacillus thermosphaericus, Thermostable amino acid dehydrogenase, Purification and characterization

\section{Introduction}

meso-Diaminopimelate dehydrogenase (meso-2,6-D-diaminopimerate dehydrogenase, meso-DAPDH, EC 1.4.1.16) catalyzes the NADP-dependent oxidative deamination of meso-2,6-diaminopimelate (meso-DAP) to produce L-2-amino-6-oxopimelate (L-2-amino-6-oxoheptanedioate). This enzyme is the only known NAD (P)-dependent dehydrogenase able to stereoselectively act on the D-configuration of meso-DAP. It has been identified in several bacteria, and is known to function

\footnotetext{
* Correspondence: ohshima@agr.kyushu-u.ac.jp

${ }^{3}$ Microbial Genetic Division, Institute of Genetic Resources, Faculty of Agriculture, Kyushu University, 6-10-1 Hakozaki, Higashi-ku, Fukuoka 8128581, Japan

Full list of author information is available at the end of the article
}

in L-lysine biosynthesis in Bacillus sphaericus (Misono et al. 1979) and Corynebacterium glutamicum (Misono et al. 1986a). In addition, it has been purified to homogeneity from B. sphaericus (Misono and Soda 1980) and Brevibacterium sp. (Misono et al. 1986b), and has been characterized enzymologically. The meso-DAPDH genes from C. glutamicum (Ishino et al. 1988) and B. sphaericus (Sakamoto et al. 2001) have been sequenced, and were found to be highly similar to one another. The $C$. glutamicum gene has been expressed in Escherichia coli cells (Reddy et al. 1996,), and the three-dimensional structures of the enzyme-NADP complex (Scapin et al. 1996,), the enzyme-substrate complex and an enzymeNADP-inhibitor complex (Scapin et al. 1998) have been 
solved for the C. glutamicum enzyme and refined to 2.2 Å resolution.

An NADP-dependent, highly stereoselective D-amino acid dehydrogenase was also prepared through mutation of C. glutamicum meso-DAPDH using both rational and random mutagenesis (Vedha et al. 2006). The mutant enzyme is potentially useful for the production of Damino acids via the reductive amination of the corresponding 2-oxo acid with ammonia. However, the mutant enzyme is not necessary stable enough to use for a long term and under various conditions. Thus, more stable meso-DAPDH and its mutant enzyme have been required. We had looked for the enzyme in thermophiles by database and the activity analyses, but were not able to find the homologous gene in sequence to that of C. glutamicum meso-DAPDH in thermophiles. Thus, we had started the screening of stable mesoDAPDH by detection of the enzyme activity in many strains of thermophiles stocked as type cultures and isolated from soils and composts, and found the activity in an aerobically well-grown thermophile from a compost. Just recently, meso-DAPDH in a thermophilic bacterium, Clostridium thermocellum was found and the enzymological properties were reported with emphasizing to show the presence of meso-DAPDH pathway in as well as a succinyl and acetyl-DAP pathway (Hudson et al, 2011). In the present study, the thermophile of mesoDAPDH producer isolated from compost was identified to be Ureibacillus thermosphaericus strain A1. The enzyme was then purified from the thermophile and characterized as a thermostable meso-DAPDH, and the gene was sequenced.

\section{Materials and methods Materials}

An illustra bacteria genomicPrep Mini Spin Kit was purchased from GE Healthcare (Buckinghamshire, UK). A HiYield ${ }^{\text {TM }}$ Plasmid Mini Kit was from RBC Bioscience (Taipei, Taiwan). A QIAquick Gel Extraction Kit was from QIAGEN (Hilden, Germany). Restriction endonucleases were purchased from Takara Bio (Shiga, Japan) and Toyobo (Osaka, Japan). Butyl Sepharose ${ }^{\mathrm{TM}} 4$ Fast Flow was from GE Healthcare. DEAE-Toyopearl M-650 was from Tosoh (Tokyo, Japan). Amicon Ultra-15 was from Millipore (Billerica, MA, USA). INT (2-(4-Iodophenyl)-3-(4-nitrophenyl)-5-phenyl-2H-tetrazolium chloride) and 1-Methoxy PMS (1-Methoxy-5-methylphenazinium methyl sulfate) were from Dojindo (Kumamoto, Japan). All other chemicals were reagent grade.

\section{Screening for meso-DAPDH in thermophiles and the growth conditions for $U$. thermosphaericus}

We isolated thermophiles from a variety of soils, sea sands, composts and mud from hot springs at $50-70^{\circ} \mathrm{C}$ using medium containing $0.5 \%$ polypeptone-S (Nihonseiyaku, Tokyo), 0.2\% meat extract (Wako Pure Chemical Industries, Osaka), $0.35 \% \mathrm{NaCl}$ and $2 \%$ agar (pH 7.2 with $\mathrm{KOH}$ ). After cultivation, the cells were collected by centrifugation $(8,000$ $\times g$ for 15 min at $4^{\circ} \mathrm{C}$ ), and the terrestrial microorganisms were washed twice with $0.85 \% \mathrm{NaCl}$, while the marine microorganisms were washed with $3 \% \mathrm{NaCl}$. The cells were then suspended with a small amount of $10 \mathrm{mM}$ potassium phosphate buffer ( $\mathrm{pH}$ 7.2) containing 10\% glycerol and stored at $-80^{\circ} \mathrm{C}$ until used. A meso-DAPDH producing thermophile, $U$. thermosphaericus strain A1 was aerobically cultured over night at $50^{\circ} \mathrm{C}$ in the liquid medium described above on a reciprocating rotor $(250 \mathrm{rpm})$. The screening procedure for detection of meso-DAPDH entailed native polyacrylamide gel electrophoresis (native-PAGE) followed by activity staining at $50^{\circ} \mathrm{C}$ with a mixture containing 300 $\mathrm{mM}$ potassium phosphate buffer ( $\mathrm{pH} 8.0), 50 \mathrm{mM}$ mesoDAP, $0.1 \mathrm{mM}$ INT, $0.04 \mathrm{mM}$ 1-Methoxy PMS and $2.5 \mathrm{mM}$ NADP until a red band of sufficient intensity had developed. Enzyme activity was then assessed spectrophotometrically as described below in the "Enzyme assay" section.

\section{S rRNA gene amplification and sequencing}

Genomic DNA was extracted from isolated bacteria using an illustra bacteria genomic Prep Mini Spin Kit and then used as the template for 16S rRNA gene amplification. DNA fragments were amplified by polymerase chain reaction (PCR) using the universal primers 27f (5'-AGAGTTTGATCMTGGCTCAG-3') and 1492r (5'-TACGGYTACCTTGTTACGACTT-3'). PCR mixture contained 10× Ex Taq buffer, $0.2 \mathrm{mM}$ dNTP mixture, $100 \mathrm{ng}$ of DNA template, $1.0 \mu \mathrm{M}$ primers $27 \mathrm{f}$ and 1492r, and $1.25 \mathrm{U}$ of Ex Taq DNA polymerase (Takara Bio) in a final volume of $50 \mu \mathrm{l}$. The PCR protocol entailed a $30 \mathrm{~s}$ denaturation at $98^{\circ} \mathrm{C}$, followed by 30 cycles of $98^{\circ} \mathrm{C}$ for $30 \mathrm{~s}, 51^{\circ} \mathrm{C}$ for $30 \mathrm{~s}$ and $72^{\circ} \mathrm{C}$ for 1.7 min and a final extension at $72^{\circ} \mathrm{C}$ for $10 \mathrm{~min}$ in TProfessional 96 Gradient (Biometra, Göttingen, Germany). The amplified PCR products were purified using Wizard $^{\circledR}$ SV Gel and a PCR Clean-up System (Promega, WI, USA) to remove unconsumed dNTPs and primers and then directly sequenced using a BigDye ${ }^{\circledR}$ Terminator v3.1 Cycle Sequencing Kit (Applied Biosystems, CA, USA) on a 3130 Genetic Analyzer.

\section{Phylogenetic analysis of the $16 \mathrm{~S}$ rRNA gene sequences}

The 16S rRNA gene sequences from the bacteria isolated in this study were aligned and clustered against those of the genus Ureibacillus (Fortina et al 2001), which was available from GenBank.

\section{Enzyme assay and protein determination}

The rate of NADP-dependent oxidative deamination of meso-DAP was spectrophotometrically determined at 
$50^{\circ} \mathrm{C}$. The standard reaction mixture (total volume: 1.00 $\mathrm{ml}$ ) contained $200 \mathrm{mM}$ carbonate- $\mathrm{KOH}(\mathrm{pH} 10.5), 10$ mM meso-DAP, $1.25 \mathrm{mM}$ NADP and enzyme. The mixture without the coenzyme (NADP) was pre-incubated at $50^{\circ} \mathrm{C}$ for about $3 \mathrm{~min}$ in a cuvette with a $1.0-\mathrm{cm}$ light path. The reaction was then started by adding $25 \mathrm{mM}$ NADP $(50 \mu \mathrm{l})$, which had also been pre-incubated at $50^{\circ}$ C. The increase in absorbance accompanied by the formation of NADPH was monitored at $340 \mathrm{~nm}$ (an extinction coefficient $=6.22 \mathrm{mM}^{-1} \mathrm{~cm}^{-1}$ ). One unit of enzyme was defined as the amount catalyzing the formation of 1 $\mu \mathrm{mol}$ of $\mathrm{NADPH} / \mathrm{min}$ at $50^{\circ} \mathrm{C}$ during meso-DAP oxidation. The protein concentration was determined by the method of Bradford (1976) using bovine serum albumin as the standard.

\section{Purification of meso-DAPDH from $U$. thermosphaericus cells}

All steps in the purification procedure were carried out at a room temperature, using $50 \mathrm{mM}$ potassium phosphate buffer ( $\mathrm{pH} 7.2)$ as the standard buffer. U. thermosphaericus cells (5.12 g, wet weight) suspended in about $20 \mathrm{ml}$ of standard buffer were disrupted by sonication (UD-201; Tomy Seiko, Tokyo), which entailed five cycles of 60-s pulses $(50 \mathrm{~W})$ followed by a 60 -s rest on ice. Thereafter, any remaining intact cells and the cell debris were removed by centrifugation $\left(27,500 \times g\right.$ for $20 \mathrm{~min}$ at $\left.4^{\circ} \mathrm{C}\right)$, and the resultant supernatant was used as the crude extract. Ammonium sulfate was added to the crude extract to $80 \%$ saturation, and the precipitate obtained by centrifugation $\left(27,500 \times g\right.$ for $20 \mathrm{~min}$ at $\left.4^{\circ} \mathrm{C}\right)$ was dissolved in standard buffer supplemented with $1 \mathrm{M}\left(\mathrm{NH}_{4}\right)_{2} \mathrm{SO}_{4}$. The resultant solution was then applied to a Butyl Sepharose $\mathrm{e}^{\mathrm{TM}}$ 4. Fast Flow column $(6.1 \times 10.0 \mathrm{~cm})$ equilibrated with standard buffer supplemented with $1 \mathrm{M}\left(\mathrm{NH}_{4}\right)_{2} \mathrm{SO}_{4}$. The column was then washed with the same supplemented buffer, and the enzyme was eluted with a linear 1.0 to $0 \mathrm{M}\left(\mathrm{NH}_{4}\right)$ ${ }_{2} \mathrm{SO}_{4}$ gradient in the same buffer. The active fractions were pooled and dialyzed against the standard buffer, after which the dialyzate was loaded onto a DEAE-Toyopearl $650 \mathrm{M}$ column $(6.1 \times 5.0 \mathrm{~cm})$ equilibrated with the standard buffer. After washing the column with standard buffer, the enzyme was eluted with a linear 0 to $0.5 \mathrm{M} \mathrm{NaCl}$ gradient in the same buffer. The active fractions were again pooled and dialyzed against the standard buffer, and preparative slab PAGE was carried out according to the method of Ohshima and Ishida (1992). Finally, the enzyme was extracted from the gel pieces using the standard buffer and Amicon Ultra-15, and the resultant enzyme solution was used for experimentation.

\section{PAGE and molecular mass determination}

Native-PAGE was carried out at $4{ }^{\circ} \mathrm{C}$ on a $7.5 \%$ polyacrylamide gel using the method of Davis (1964). The protein was then stained using $0.025 \%$ Coomassie brilliant blue R-250 in 50\% methanol and 10\% acetate. In addition, active staining was performed at $50^{\circ} \mathrm{C}$ using a mixture containing $300 \mathrm{mM}$ potassium phosphate buffer (pH 8.0), 50 mM meso-DAP, $0.1 \mathrm{mM}$ INT, 0.04 mM 1Methoxy PMS and 1.25 mM NADP until a red band of sufficient intensity was visible.

Sodium dodecyl sulfate (SDS)-PAGE was carried out on a $10 \%$ polyacrylamide gel using the method of Laemmli (1970). Precision Plus protein standards (BioRad Laboratories, CA, USA) were used as the molecular mass standards. The protein sample was boiled for 5 min in $10 \mathrm{mM}$ Tris- $\mathrm{HCl}$ buffer ( $\mathrm{pH} \mathrm{7.0)} \mathrm{containing} 1 \%$ SDS and 1\% 2-mercaptoethanol. Protein bands were visualized by staining with $0.025 \%$ Coomassie brilliant blue R-250 in 50\% methanol and 10\% acetate.

The molecular mass of the native enzyme was determined by gel filtration column chromatography using a Superdex 200 pg column $(2.6 \times 60 \mathrm{~cm})$. Ferritin $(440$ $\mathrm{kDa})$, aldolase $(158 \mathrm{kDa})$, conalbumin $(75 \mathrm{kDa})$, ovalbumin (43 kDa) and $\alpha$-chymotrypsinogen (25 kDa) served as molecular standards (GE Healthcare).

\section{Determination of kinetic parameters}

The Michaelis constant $\left(K_{\mathrm{m}}\right)$ was determined from double-reciprocal plots of the initial rate data using mesoDAP as the electron donor and NADP as the electron acceptor at $50^{\circ} \mathrm{C}$.

\section{$\mathrm{N}$-Terminal amino acid sequence analysis}

The N-terminal amino acid sequence of the isolated enzyme was analyzed using an automated Edman degradation protein sequencer. The phenylthiohydantoin derivatives were separated and identified using a Shimadzu PPSQ-10 protein sequencer (Shimadzu, Kyoto, Japan).

\section{Purification of genomic DNA}

To obtain genomic DNA for meso-DAPDH gene sequencing, genomic DNA was prepared from $U$. thermosphaericus as follows. U. thermosphaericus cells (about $1 \mathrm{~g}$, wet weight) were suspended in $10 \mathrm{ml}$ of 50 $\mathrm{mM}$ Tris- $\mathrm{HCl}$ buffer ( $\mathrm{pH}$ 8.0) containing 50 mM EDTA, $10 \mathrm{mg}$ of lysozyme per $\mathrm{ml}$ and $100 \mathrm{mg}$ of proteinase $\mathrm{K}$ (Nacalai Tesque, Kyoto) per $\mathrm{ml}$, and incubated for $3 \mathrm{~h}$ at $37^{\circ} \mathrm{C}$. This was followed by addition of $10 \%$ SDS $(1.2$ $\mathrm{ml}$ ) and incubation for $15 \mathrm{~min}$ at $65^{\circ} \mathrm{C}$, after which CTAB-NaCl solution $(1.5 \mathrm{ml}$ of $100 \mathrm{mM}$ Tris- $\mathrm{HCl}(\mathrm{pH}$ 9.0), $10 \mathrm{mM}$ EDTA, $1.4 \mathrm{M} \mathrm{NaCl}$ and $2.0 \%$ cetyltrimethylammonium bromide solution) was added, and the cells were incubated for an additional $15 \mathrm{~min}$ at $65^{\circ} \mathrm{C}$. The proteins in the mixture were then extracted several times with phenol-chloroform, and the genomic DNA was precipitated first with 2.5 volumes of $100 \%$ ethanol supplemented with $60 \mu \mathrm{l}$ of $3 \mathrm{M}$ sodium acetate buffer 
( $\mathrm{pH} 5.2$ ), and then with 2.5 volumes of $70 \%$ ethanol for demineralization. To remove any contaminating RNA, RNase was then added to the solution and incubated for $3 \mathrm{~h}$ at $37^{\circ} \mathrm{C}$.

\section{Screening for meso-DAPDH gene}

For clonining of the meso-DAPDH gene from $U$. thermosphaericus, a homology search was carried out among the related strains using the NCBI BLAST program. Based on the highly-conserved regions of mesoDAPDH genes, a set of degenerated primers (forward: 5'-GGRATYGTMGGWTAYGGRAAY-3' [where $M$ is A or $C$; $R$ is $A$ or $G$; $W$ is $A$ or $T$ and $Y$ is $C$ or $T$ ], reverse: 5'-RACRAAWCCKCCRTGWGG-3' [where $\mathrm{K}$ is G or $T ; R$ is $A$ or $G$ and $W$ is $A$ or $T$ ]) were designed for the partial amplification of meso-DAPDH gene from $U$. thermosphaericus. PCR was performed by 30 cycles of $98^{\circ} \mathrm{C}$ for $30 \mathrm{~s}, 51^{\circ} \mathrm{C}$ for $30 \mathrm{~s}$ and $72^{\circ} \mathrm{C}$ for $50 \mathrm{sec}$ with Ex Taq DNA polymerase. The amplified PCR products were purified and directly sequenced. The complete sequence of the meso-DAPDH gene was obtained using an in vitro Cloning Kit (Takara Bio) according to the manufacturer's instructions.

\section{Sequence analysis}

The sequence obtained as described above was identified by using the NCBI BLAST program to run similarity searches against other sequences from available databases. The sequences were then aligned using ClustalW (Larkin et al. 2007), and multiple sequence alignment of meso-DAPDHs (Figure 1) was generated.

\section{Expression of meso-DAPDH gene and purification of the gene product}

meso-DAPDH gene was amplified using KOD -plusDNA polymerase (Toyobo) with primers 5 '-CACCATGAGTAAAATTAGAATTGGG-3' (forward) and 5'TAAAAGTTCTTTTCTTAAATCTTCTGGAG-3'

(reverse), and then cloned using a Champion ${ }^{\mathrm{TM}}$ pET 101 Directional TOPO Expression Kit (invitrogen, CA, USA), yielding the expression plasmid pET101/DAPDH. E. coli Rosetta (DE3) cells were transformed with pET101/DAPDH, after which the transformants were grown in $\mathrm{LB}$ medium (1\% Triptone, $1 \% \mathrm{NaCl}$ and $0.5 \%$ yeast extract) containing $0.01 \%$ ampicillin at $37^{\circ} \mathrm{C}$. After $6 \mathrm{~h}$ of cultivation, IPTG $(1 \mathrm{mM})$ was added, and the cultivation was continued for an additional $2 \mathrm{~h}$ at $37^{\circ} \mathrm{C}$. The cells were then collected by centrifugation $(8,000 \times$ $g$ for $15 \mathrm{~min}$ at $4^{\circ} \mathrm{C}$ ), resuspended in standard buffer, and disrupted by sonication as described above. After removing the debris by centrifugation $(27,500 \times g$ for 20 $\min$ at $4^{\circ} \mathrm{C}$ ), the supernatant was incubated for $30 \mathrm{~min}$ at $50^{\circ} \mathrm{C}$ (heat-treatment) and centrifuged $(27,500 \times g$ for $20 \mathrm{~min}$ at $4^{\circ} \mathrm{C}$ ) again to remove the unwanted proteins derived from the bacteria. The resultant solution was loaded onto a Chelating Sepharose ${ }^{\mathrm{TM}}$ Fast Flow column $(6.1 \times 6.0 \mathrm{~cm})($ GE Healthcare $)$ previously equilibrated with buffer containing $50 \mathrm{mM} \mathrm{NiSO} 4,20 \mathrm{mM}$ Tris- $\mathrm{HCl}$ (pH 7.9), $500 \mathrm{mM} \mathrm{NaCl}$ and $5 \mathrm{mM}$ imidazole. The column was then washed with washing buffer $(20 \mathrm{mM}$ Tris- $\mathrm{HCl}$ ( $\mathrm{pH}$ 7.9), $500 \mathrm{mM} \mathrm{NaCl}, 60 \mathrm{mM}$ imidazole), and the adsorbed proteins were eluted with the elution buffer (20 mM Tris-HCl (pH 7.9), $500 \mathrm{mM} \mathrm{NaCl}$ and 1 $\mathrm{M}$ imidazole). The active fractions were pooled and dialyzed against the standard buffer.

\section{Results}

\section{Screening for meso-DAPDH in thermophiles}

When we started this study about 2 years ago, there was no report on meso-DAPDH from thermophile as the producer of more stable meso-DAPDH. Thus, we screened more than 100 strains of aerobically grown thermophiles isolated from various soil samples by incubation at $50^{\circ} \mathrm{C}$ and $70^{\circ} \mathrm{C}$, and detected meso-DAPDH activity in a thermophile isolated from compost obtained from Munakata City in Fukuoka Prefecture, Japan. When cultured in liquid medium, the thermophilic strain grew at temperatures between $37^{\circ} \mathrm{C}$ and $55^{\circ} \mathrm{C}$, but not at $60^{\circ} \mathrm{C}$, and maximum growth was achieved at $50^{\circ}$ C. The crude extract from the cells included a high level of meso-DAPDH activity when NADP served as a coenzyme. To identify the thermophile, we determined the sequence of the $16 \mathrm{~S}$ rRNA gene $(1425 \mathrm{bp}$; accession number: AB671590), which was found to be completely identical to that of $U$. thermosphaeicus (accession number: X90640). Thus, the isolated strain was identified as $U$. thermosphaeicus strain A1 and deposited to Biological Resource Center (NBRC), National Institute of Technology and Evaluation (strain number: NBRC 108682).

\section{Purification of meso-DAPDH from the $U$. thermosphaeicus}

We collected $5.14 \mathrm{~g}$ (wet weight) of $U$. thermosphaeicus cells from $500 \mathrm{ml}$ of culture medium, and then obtained about $260 \mathrm{mg}$ of soluble protein from the crude cell extract after sonication and centrifugation. The purified enzyme was then isolated using the five-step procedure described in the materials and methods. The purified meso-DAPDH migrated as a single band on both native PAGE (Figure 2A) and SDS-PAGE (Figure 2B), indicating the enzyme had been purified to homogeneity (Table 1). At the final step, the enzyme was purified about 47 -fold, with an overall yield of about $4.69 \%$.

\section{Molecular mass and subunit structure}

Following native-PAGE, the molecular mass of the $U$. thermosphaeicus meso-DAPDH was determined to be about 80 kDa using Superdex 200 pg column gel filtration chromatography (data not shown). SDS-PAGE of 


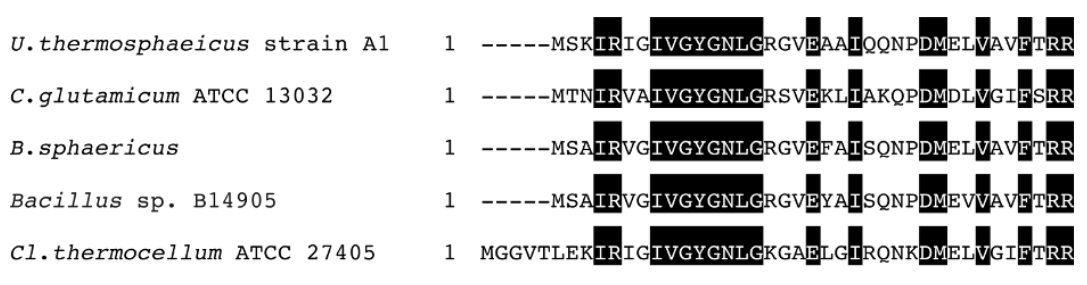

U. thermosphaeicus strain A1

C.glutamicum ATCC 13032

B. sphaericus

Bacillus sp. B14905

Cl.thermocellum ATCC 27405

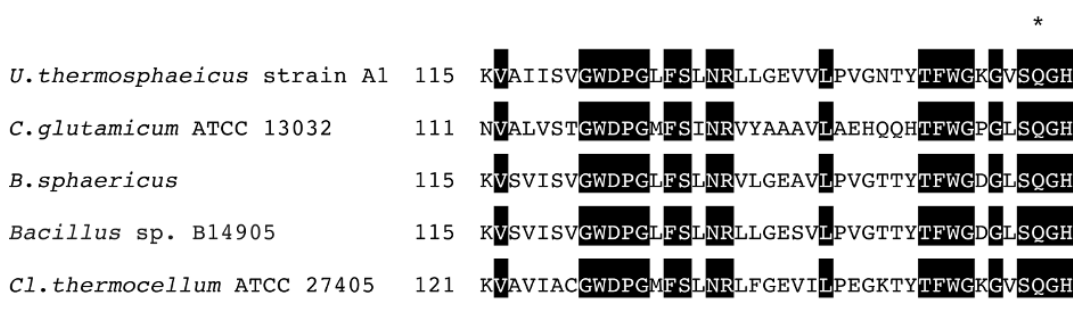

U. thermosphaeicus strain A1

C.glutamicum ATCC 13032

B. sphaericus

Bacillus sp. B14905

Cl.thermocellum ATCC 27405

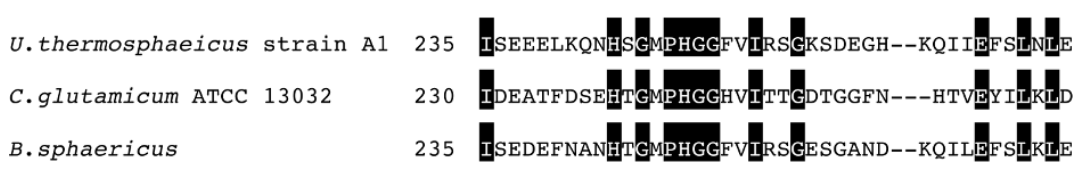

Figure 1 Multiple sequence alignment of meso-DAPDHs. The accession numbers of the aligned sequences are C. glutamicum ATCC13032 (YP_226858), B. sphaericus (BAB07799), Bacillus sp. B14905 (ZP_01724569), Cl. thermocellum ATCC27405 (ABN52156). Amino acid residues mutated for the creation of D-amino acid.

the enzyme showed one major band of $40 \mathrm{kDa}$ (Figure $2 \mathrm{~B})$, suggesting that the enzyme is composed of two identical subunits.

Effects of $\mathrm{pH}$, temperature and various chemicals on enzyme activity and stability

The effect of $\mathrm{pH}$ on the oxidative deamination of mesoDAP was determined by assessing the enzyme activity at various pHs. At a temperature of $50^{\circ} \mathrm{C}$, the optimum $\mathrm{pH}$ was about 10.5. When the temperature dependence of the catalytic activity at $\mathrm{pH} 10.5$ was examined, maximum activity was observed at around $65^{\circ} \mathrm{C}$. Moreover, when the enzyme was incubated for $30 \mathrm{~min}$ at various temperatures in the standard buffer at $\mathrm{pH} 7.2$, no activity was lost at temperatures below $60^{\circ} \mathrm{C}$, while half of the activity was lost at $65^{\circ} \mathrm{C}$ (Figure 3 ). When the effect of $\mathrm{pH}$ on the stability of the enzyme was evaluated based on the activity remaining after incubation at $50^{\circ} \mathrm{C}$ for $30 \mathrm{~min}$, no loss of activity was observed at $\mathrm{pHs}$ between 5.0 and 11.0 (data not shown). 


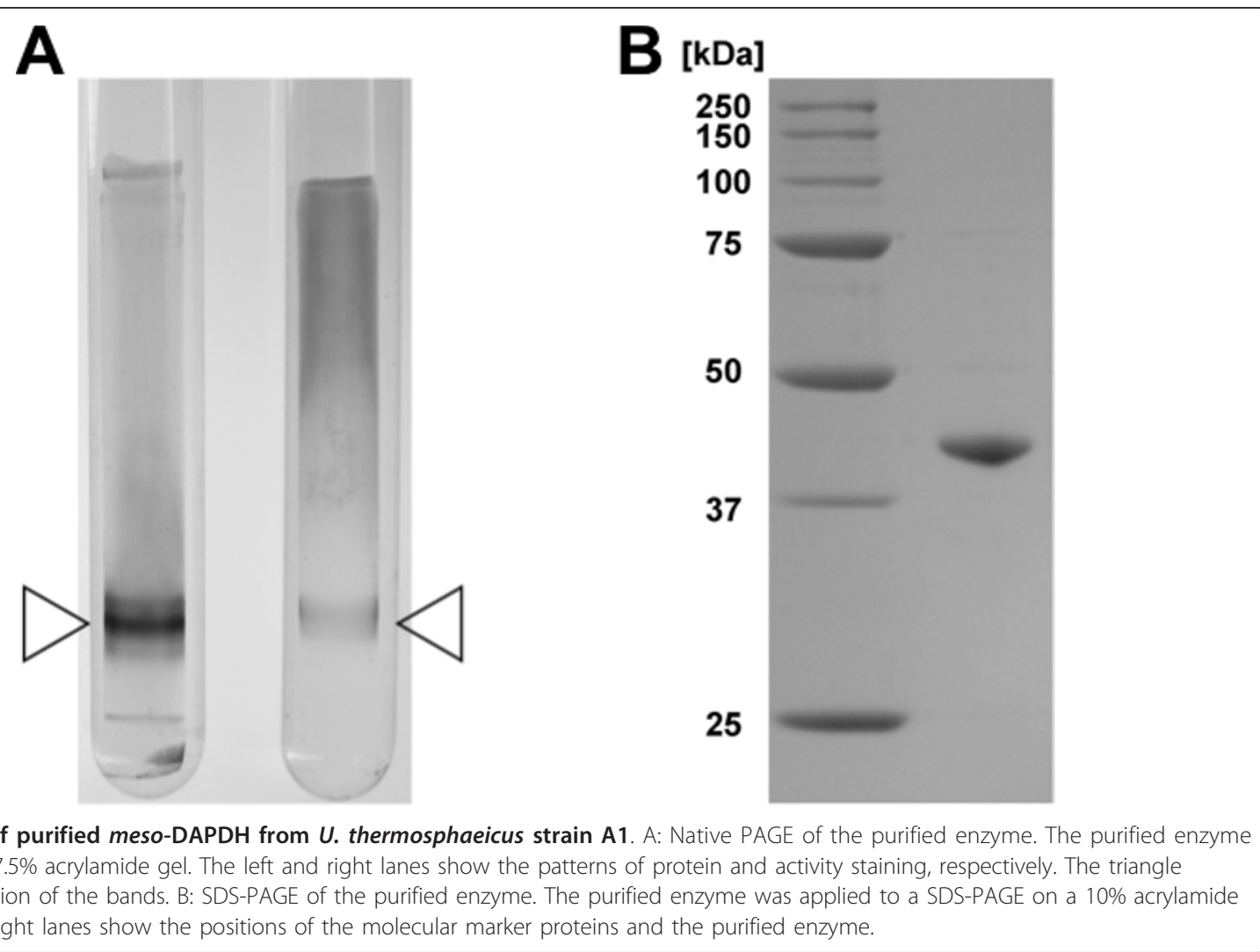

\section{Substrate and coenzyme specificities}

Examination of the substrate specificity of the oxidative deamination of amino acids revealed that meso-DAP was the only effective substrate in presence of NADP. The enzyme was highly specific for meso-DAP as the electron donor, and the following amino acids were inert: DL-2aminopimelate, D-glutamate, L-glutamate, D-aspartate, L-aspartate, D-alanine, L-alanine, D-valine, L-valine, Dlysine, L-lysine, D-phenylalanine, L-phenylalanine, D-leucine, L-leucine, D-threonine, L-threonine, D-serine, Lserine, D-tryptophan, L-tryptophan, D-cysteine, Lcysteine, D-histidine, L-histidine, D-methionine, D-arginine, $\mathrm{D}$-proline, $\mathrm{D}$-asparagine, $\mathrm{D}$-glutamine, $\mathrm{D}$-isoleucine

Table 1 Purification of NADP-dependent meso-DAPDH from $U$. thermosphaeicus

\begin{tabular}{lllll}
\hline Purification step $^{\text {a }}$ & $\begin{array}{l}\text { Total } \\
\text { protein } \\
\text { mg }\end{array}$ & $\begin{array}{l}\text { Total } \\
\text { activity } \\
\text { units }\end{array}$ & $\begin{array}{l}\text { Specific } \\
\text { activity } \\
\text { units/ } \\
\text { mg }\end{array}$ & Yield \\
\hline Crude extract & 264 & 46.6 & 0.177 & 100 \\
80\% Ammonium sulfate & 162 & 44.5 & 0.274 & 95.5 \\
Butyl SepharoseTM 4 Fast Flow & 15.1 & 15.7 & 1.04 & 33.7 \\
column & & & & \\
DEAE-Toyopearl 650M column & 2.90 & 5.01 & 1.73 & 10.8 \\
Preparative slab PAGE & 0.264 & 2.19 & 8.28 & 4.69 \\
\hline
\end{tabular}

a) The cells were obtained from a $500 \mathrm{ml}$-medium. and D-ornithine. Moreover, the enzyme exclusively used NADP as the coenzyme (electron acceptor) for the oxidative deamination of meso-DAP; NAD was inert.

\section{Inhibitors}

The enzyme was completely inhibited by both $0.1 \mathrm{mM} p$ chloromercuribenzoate and $\mathrm{HgCl}_{2}$, which are typical inhibitors of $\mathrm{SH}$ enzymes. Thioglycollate $(5 \mathrm{mM}), \mathrm{L}-$ cysteine $(5 \mathrm{mM})$ and $\mathrm{Cu}^{2+}(1 \mathrm{mM})$ also strongly inhibited the enzyme. Several other metal ions $(1 \mathrm{mM})$, including $\mathrm{Zn}^{2+}, \mathrm{Co}^{2+}$ and $\mathrm{Ni}^{2+}$ were not inhibitory, nor did $1 \mathrm{mM}$ D-lysine, L-lysine, EDTA, $\alpha, \alpha^{\prime}$-dipyridyl, $\mathrm{NaN}_{3}$ or iodoacetic acid affect the oxidative deamination of meso-DAP.

\section{Kinetic studies}

Analysis of the initial velocity of the oxidative deamination of meso-DAP in the presence of NADP yielded typical Michaelis-Menten kinetics. As determined from Lineweaver-Burk plots, the apparent $K_{\mathrm{m}}$ values at $50^{\circ} \mathrm{C}$ in cabonate- $\mathrm{KOH}$ buffer ( $\mathrm{pH} 10.5)$ were $1.6 \mathrm{mM}$ and $0.13 \mathrm{mM}$ for meso-DAP and NADP, respectively.

\section{$\mathrm{N}$-Terminal amino acid sequencing}

Using an automated Edman degradation protein sequencer, the N-terminal amino acid sequence of the subunit was determined to be SKIRIGIVGY. 


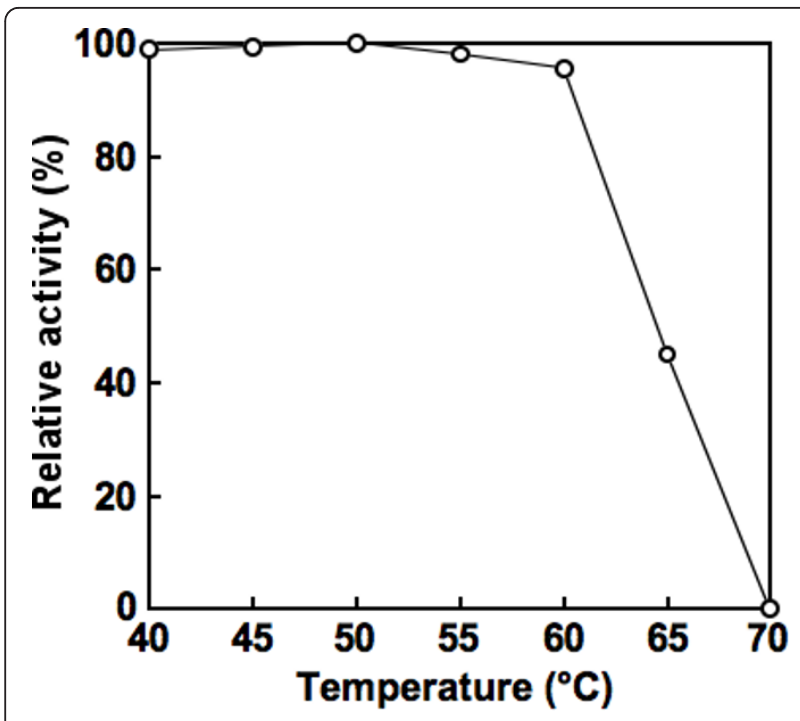

Figure 3 Effect of temperature on the activity of NADPdependent meso-DAPDH from $U$. thermosphaericus strain A1. After the enzyme (in $10 \mathrm{mM}$ potassium phosphate buffer, $\mathrm{pH}$ 7.2) was incubated for $30 \mathrm{~min}$ at each temperature, the residual activity was determined using the standard assay at $50^{\circ} \mathrm{C}$.

\section{Gene sequencing}

To identify the meso-DAPDH gene in the chromosome of $U$. thermosphaeicus, in vitro cloning was performed as described in materials and methods with information of $\mathrm{N}$-terminal amino acid sequence. Sequencing of the fragment revealed a single 981-bp open reading frame encoding 326 amino acids (accession number: AB636161), and the deduced N-terminal amino acid sequence was identical to that obtained by protein sequencing. An NCBI BLAST search revealed the amino acid sequence of $U$. thermosphaeicus meso-DAPDH to be highly homologous with the sequence of mesoDAPDH from B. sphaericus (80\%), Bacillus sp. B14905 (79\%), Cl. thermocellum ATCC 27405 (64\%) and with those from the putative meso-DAPDHs from Lysinibacillus fusiformis ZC1 (80\%), L. sphaericus C3-41 (80\%), Cl. tetani E88 (66\%) and Herminiimonas arsenicoxydans (66\%).

Purification and characterization of recombinant mesoDAPDH expressed in $E$. coli

After transformation of E. coli Rosetta (DE3) cells with pET101/DAPDH, which harbored the recombinant meso-DAPDH gene, a high level of meso-DAPDH production was found in the crude extract of the transformants. The recombinant meso-DAPDH was easily purified about 2.4-fold, with an overall yield of about $53.1 \%$, by successive heat-treatment and Chelating Sepharose Fast Flow column chromatography steps. With this procedure, we obtained $54.6 \mathrm{mg}$ of the purified protein from $2.38 \mathrm{~g}$ (wet weight) of E. coli cells (Table 2).

The maximum activity of the purified recombinant meso-DAPDH was detected at $65^{\circ} \mathrm{C}$ in carbonate- $\mathrm{KOH}$ buffer at $\mathrm{pH} 10.5$. Full activity was retained after incubation at $60^{\circ} \mathrm{C}$ for $30 \mathrm{~min}$, but activity was completely lost after incubation at $70^{\circ} \mathrm{C}$ for $30 \mathrm{~min}$. There was no significant difference in the enzyme stability or the molecular mass between the purified native meso-DAPDH and the purified recombinant meso-DAPDH.

\section{Discussion}

Misono et al. (1979),; (1986a) previously described the relatively wide distribution of meso-DAPDHs among mesophilic bacteria, including B. sphaericus, Brevibacterium sp., C. glutamicum and Proteus vulgaris. The presence of meso-DAPDH in thermophile has not been found until the recent report on the enzyme from an anerobic Cl. thermocellum (Hudson et al. 2011). We found one enzyme producer in many aerobic thermophiles by extensive screening. The thermophile was identicafied to be $U$. thermosphaeicus strain A1. This is the first producer of meso-DAPDH in aerobic thermophile.

As expected, meso-DAPDH purified from $U$. thermosphaericus is much more thermostable than its counterparts from mesophiles, such as B. sphaericus (Misono and Soda 1980) and C. glutamicum (Misono et al 1986a): the $U$. thermosphaericus enzyme showed almost no loss of activity after incubation for $30 \mathrm{~min}$ at temperatures up to $60^{\circ} \mathrm{C}$, whereas the mesophilic enzymes lost their activity within $10 \mathrm{~min}$ at temperatures above $48^{\circ} \mathrm{C}$. There is no report with respect to the thermostability of the Cl. thermocellum enzyme (Hudson et al. 2011). In addition, the $U$. thermosphaericus enzyme is highly stable over wider range of pHs (no loss of activity at $\mathrm{pH} 5.0$ to 11.0 after incubation for $30 \mathrm{~min}$ at $50^{\circ} \mathrm{C}$ ) than the mesophilic enzymes (Brevibacterium sp. enzyme: stable at pH 7.0-9.0 after $10 \mathrm{~min}$ at $40^{\circ} \mathrm{C}$; $C$. glutamicum enzyme: stable at $\mathrm{pH}$ 6.5-7.0 after $10 \mathrm{~min}$ at $48^{\circ} \mathrm{C}$ ) (Misono et al $\left.1986 \mathrm{a}, \mathrm{b}\right)$. The higher stability of the $U$. thermosphaericus enzyme under the various

Table 2 Purification of recombinant NADP-dependent meso-DAPDH from $E$. coli

\begin{tabular}{lllll}
\hline Purification step $^{\mathbf{b}}$ & $\begin{array}{l}\text { Total } \\
\text { protein } \\
\text { mg }\end{array}$ & $\begin{array}{l}\text { Total } \\
\text { activity } \\
\text { units }\end{array}$ & $\begin{array}{l}\text { Specific } \\
\text { activity } \\
\text { units/ } \\
\text { mg }\end{array}$ & Yield \\
\hline Crude extract & 250 & 796 & 3.18 & 100 \\
Heat-treatment & 198 & 694 & 3.51 & 87.1 \\
$\begin{array}{l}\text { Chelating Sepharose } \\
\text { column }\end{array}$ & 54.6 & 423 & 7.75 & 53.1 \\
\hline
\end{tabular}

b) The cells were obtained from a $500 \mathrm{ml}$-medium 
conditions tested suggests it would be more useful and easier to obtain in a highly purified form needed for bioprocesses. Still, the dimeric structure of the $U$. thermosphaericus meso-DAPDH and its narrow substrate specificity for meso-DAP and NADP indicates that it is not very different against mesophilic counterparts.

We also succeeded in cloning and sequencing the mesoDAPDH gene from $U$. thermosphaericus, which enabled us to greatly enhance production of the enzyme in recombinant $E$. coli cells. The increased production was in part due to the much more effective method of purification, which had a yield of $53.1 \%$ from the recombinant cells, as compared to $4.69 \%$ from $U$. thermosphaericus cells. Vedha et al. (2006) used a protein engineering method to create a highly stereoselective NADP-dependent D-amino acid dehydrogenase with broad substrate specificity from $C$. glutamicum meso-DAPDH and showed its application for one-step synthesis of D-amino acids from their oxo analogs. The sequence alignment of meso-DAPDHs of $U$. thermosphaericus and other four bacterial strains indicates that all five amino acids (Q150, D154, T169, R195 and H244) in C. glutamicum enzyme mutated for the creation of D-amino acid dehydrogenase are perfectly conserved in the sequences of other bacterial enzymes containing $U$. thermosphaericus enzyme (Figure 1 ). The U. thermosphaericus meso-DAPDH is much more stable than the $C$. glutamicum meso-DAPDH just mentioned. Thus, the $U$. thermosphaericus enzyme has the potential for use in the creation of a more stable stereoselective NADP-linked Damino acid dehydrogenase. In addition to altering its substrate specificity, we are planning to create a novel stable NAD-linked D-amino acid dehydrogenase by designing its coenzyme specificity based on the sequence data from $U$. thermosphaericus meso-DAPDH and detailed information about the 3D-structure (Scapin et al 1996,) and active sites (Scapin et al. 1998) of the C. glutamicum enzyme. Such an NAD or NAD(P)-dependent D-amino acid dehydrogenase could be highly useful in a variety of bioprocesses for the production and sensing of D-amino acids and their analogs. Furthermore, we have already identified some putative meso-DAPDH genes in hyperthermophilic bacteria like Thermotoga species by sequence database, and the functional analyses of meso-DAPDH gene homolog in Thermotoga species are now under investigation.

\footnotetext{
Acknowledgements

We thank to Prof. Yutaka Kawarabayashi and Dr. Hiroaki Matsukawa for their kind advice. This work was supported by a grant for Promotion of Basic Research Activities for Innovate Bioscience from the Bio-oriented Technology Research Advancement Institution (BRAIN) and Geo Biotechnology Development Organization.

\section{Author details}

${ }^{1}$ Applied Molecular Microbiology and Biomass Chemistry, Bioscience and Biotechnology, Faculty of Agriculture, Kyushu University, 6-10-1 Hakozaki, Higashi-ku, Fukuoka 812-8581, Japan ${ }^{2}$ Center for Research and Advancement
}

in Higer Education, Kyushu University, 744 Motooka, Nishi-ku, Fukuoka 8190395, Japan ${ }^{3}$ Microbial Genetic Division, Institute of Genetic Resources, Faculty of Agriculture, Kyushu University, 6-10-1 Hakozaki, Higashi-ku, Fukuoka 812-8581, Japan

\section{Competing interests}

The authors declare that they have no competing interests.

Received: 11 October 2011 Accepted: 25 November 2011 Published: 25 November 2011

\section{References}

Bradford MM (1976) A rapid and sensitive method for the quantitation of microgram quantities of protein utilizing the principle of protein-dye binding. Anal Biochem 72:248-254. doi:10.1016/0003-2697(76)90527-3.

Davis BJ (1964) Disc electrophoresis - II method and application to human. Ann N Y Acad Sci 121:404-427

Fortina MG, Pukall R, Schumann P, Mora D, Parini C, Manachini PL, Stackebrandt E (2001) Ureibacillus gen. nov., a new genus to accomodate Bacillus thermosphaericus (Andersson et al. 1995), emendation of Ureibacillus thermosphaericus and description of Ureibacillus terrenus sp. nov. Int J Syst Evol Microbiol 51:447-455

Hudson AO, Klartag A, Gilvarg C, Dobson RC, Marques FG, Leustek T (2011) Dual diaminopimelate biosynthesis pathways in Bacteroides fragilis and Clostridium thermocellum. Biochim Biophys Acta 1814:1162-1168

Ishino S, Mizukami T, Yamaguchi K, Katsumata R, Araki K (1988) Cloning and sequencing of the meso-diaminopimelate-D-dehydrogenase (ddh) gene of Corynebacterium glutamicum. Agric Biol Chem 52:2903-2909. doi:10.1271/ bbb1961.52.2903.

Laemmli UK (1970) Cleavage of structural proteins during the assembly of the head of bacteriophage T4. Nature 227:680-685. doi:10.1038/227680a0.

Larkin MA, Blackshields G, Brown NP, Chenna R, McGettigan PA, McWilliam H, Valentin F, Wallace IM, Wilm A, Lopez R, Thompson JD, Gibson TJ, Higgins DG (2007) Clustal W and Clustal X version 2.0. Bioinformatics 23:2947-2948. doi:10.1093/bioinformatics/btm404.

Misono H, Togawa H, Yamamoto T, Soda K (1979) meso-a, $\varepsilon$-Diaminopimelate Ddehydrogenase: distribution and the reaction product. J Bacteriol 137:22-27

Misono H, Ogasawara M, Nagasaki S (1986) Characterization of mesodiaminopimelate dehydrogenase from Corynebacterium glutamicum and its distribution in bacteria. Agric Biol Chem 50:2729-2734. doi:10.1271/ bbb1961.50.2729.

Misono H, Ogasawara M, Nagasaki S (1986) Purification and properties of mesodiaminopimelate dehydrogenase from Brevibacterium sp. Agric Biol Chem 50:1329-1330. doi:10.1271/bbb1961.50.1329.

Misono H, Soda K (1980) Properties of meso-a, $\varepsilon$-diaminopimelate Ddehydrogenase from Bacillus sphaericus. J Biol Chem 255:10599-10605

Ohshima T, Ishida M (1992) A large-scale preparative electrophoretic method for the purification of pyridine nucleotide-linked dehydrogenases. Protein Expr Purif 2:121-125

Reddy SG, Scapin G, Blanchard JS (1996) Expression, purification, and crystallization of meso-diaminopimelate dehydrogenase from Corynebacterium glutamicum. Proteins 4:514-516

Sakamoto S, Seki M, Nagata S, Misono H (2001) Cloning, sequencing, and expression of the meso-diaminopimelate dehydrogenase gene from Bacillus sphaericus. J Mol Catal B Enzym 12:85-92. doi:10.1016/S1381-1177(00)00207-1.

Scapin G, Reddy SG, Blanchard JS (1996) Three-dimensional structure of mesodiaminopimelic acid dehydrogenase from Corynebacterium glutamicum. Biochemistry 35:13540-13551. doi:10.1021/bi961628i.

Scapin G, Cirilli M, Reddy SG, Blanchard JS (1998) Substrate and inhibitor binding sites in Corynebacterium glutamicum diaminopimelate dehydrogenase. Biochemistry 37:3278-3285. doi:10.1021/bi9727949.

Vedha PK, Gunawardana M, Rozzell JD, Novick SJ (2006) Creation of a broadrange and highly stereoselective D-amino acid dehydrogenase for the onestep synthesis of D-amino acids. J Am Chem Soc 128:10923-10929. doi:10.1021/ja0603960

doi:10.1186/2191-0855-1-43

Cite this article as: Akita et al:: Highly stable meso-diaminopimelate dehydrogenase from an Ureibacillus thermosphaericus strain A1 isolated from a Japanese compost: purification, characterization and sequencing. AMB Express 2011 1:43. 